\title{
LAZULI BUNTINGS IN MANITOBA
}

\author{
by Brian N. Turner, Atomic Energy of Canada, Limited, \\ Whiteshell Nuclear Research Establishment, Pinawa, Manitoba
}

The Lazuli Bunting (Passerina amoena) breeds in Canada from southcentral British Columbia to central Saskatchewan (Godfrey, 1966; Figure $1)$, but is an infrequent visitor of Manitoba. The Manitoba Museum of Man and Nature check-list records it as of "irregular occurrence", and it has been reported only six times since an initial sighting in 1928 (Table 1, Figure 2). The occurrence of two independent sightings in the fall of 1971 prompted a summary of previous records.

Once seen, the Lazuli Bunting (especially the male) is not likely to be forgotten. The turquoise-blue upper parts and throat of the male allow it to be confused only with bluebirds or the closely related Indigo Bunting (Passerina cyanea). However, double, white wing-bars, cinnamon upper breast and finch-like bill distinguish the Lazuli. The Indigo Bunting lacks the wing bars and cinnamon breast, has a blue rather than white abdomen, and is a deeper blue above and below. The brownish female Lazuli also shows the wing bars and breast colouration, along with a hint of blue on some of the upper surfaces.

The Lazuli Bunting is characteristically a western species, the Indigo an eastern one. At least since the last Pleistocene glaciation the two species have been separated by the Great Plains grasslands. However, man's alteration of the grasslands through the planting of shelterbelts and control of fire has allowed both species to extend their ranges, resulting in overlap and hybridization (Sibley and Short, 1959).

Lazulis winter from southern Baja California and southern Arizona south to south-central Mexico (Godfrey, 1966). Their northward migration begins in late March, and they eventually occupy a breeding distribution in Canada extending from southern British Columbia to south-central Sas- katchewan (Godfrey, 1966), and probably to southeastern iSaskatchewan, where Godfrey (personal communication) observed one, or possibly two, singing males at Estevan in June, 1968. Nero and Lein (1971:49) collected two male Lazuli Bunting X Indigo Bunting hybrids at Moose Mountain, Saskatchewan, June 4 and June 18, 1965. One had predominantly Lazuli features, the other, predominantly Indigo features. The species has been reported from most counties of western North Dakota (R. E. Stewart, personal communication) with a number of North Dakota sightings near the Canada-United States border, extending to about 50 miles east of the Saskatchewan-Manitoba border. Bent (1968) noted reports from extreme northeastern South Dakota, and from Minnesota and Iowa.

Typical habitat includes clearings, shelterbelts, woodland edges and brushy areas (Sibley and Short, 1959; Godfrey, 1966; Bent, 1968). Grinnell and Miller (cited in Bent, 1968) emphasize a "low dense tangle" is used for nesting. In North Dakota preferred habitats are wood-bordered streams, semiopen woodlands on prominent hills and escarpments, and well-drained floodplains of major streams (R. E. Stewart, personal communication).

The observation prompting this report occurred on October 11, 1971 at Pinawa, Manitoba (Figure 2). At about 4 p.m., Ian Hamilton (of Castlegar, British Columbia) and I saw a small flock of sparrow-sized birds on power line wires at the eastern periphery of Pinawa. As we approached by car, the flock flew approximately 150 feet farther along the road, then settled on the wires again. We parked below them within about 25 feet, and using binoculars and Peterson's (1961) guide, identified several as Lazuli Buntings. The stubby bill, white wing bars, two-coloured breast and blue parts of the male were all evident. At 


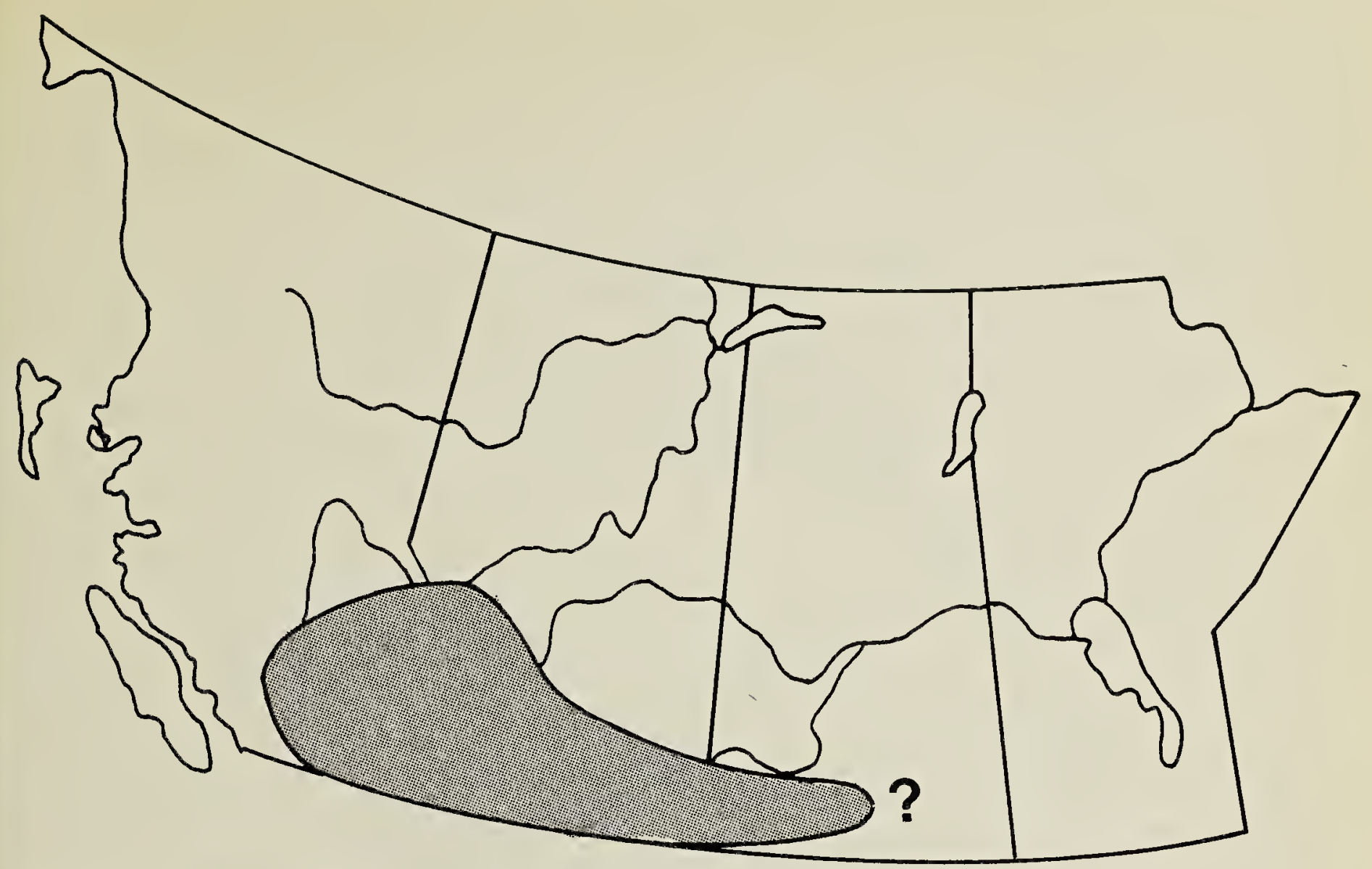

Fig. 1 Breeding distribution of Lazuli Bunting in Canada. From Godfrey (1966).

one point a male and female perched beside each other, allowing comparison of the sexes. The rather plain female would have been difficult to identify without the distinctively coloured male present. We identified at least six Lazulis, and guessed that other small birds nearby were of the same species. Weather at the time of the sighting was $44^{\circ} \mathrm{F}$, with a NNW wind of 7 mph and broken cloud.

The sighting was within several hundred yards of the Winnipeg River, in an area that is mainly boreal forest. The woods adjacent to the power line was composed of 15-20 foot trembling aspen (about half of their leaves had fallen), with scattered white spruce. The portion of woods was about 150 feet wide, between the road and golf course fairway. The main shrubs were hazel and rose (many bearing hips), with plentiful seeding thistles, sowthistles, goldenrod and asters present. On the day after the sighting, we returned with cameras, but the buntings were no longer present, and the species still remains to be verified by photograph or specimen in Manitoba.
Another possible occurrence of Lazuli Buntings in Manitoba was reported to me by Wayne Cowan, a zoology graduate student, University of Manitoba. A flock of about 20 birds believed by him to be male Lazuli Buntings was sighted on October 5, 1971 about onehalf mile north of Inwood and about 65 miles northwest of Pinawa (Figure 2 ). The birds were seen on the ground in a pasture, on a fence and in adjacent trees on a cool, sunny day. Unfortunately, no binoculars were available and they were observed no closer than 50 feet. The number of individuals reported is unusually large for this species and the sighting was made under poor circumstances. Nevertheless, though unverified, this record is of interest in view of our Pinawa observation less than a week later.

There are several unique aspects to the Pinawa sighting. This is apparently the first report of the female Lazuli Bunting in Manitoba. Since the females are rather plain, only a very experienced birdwatcher would recognize them if males were not present. Pinawa represents the most easterly 


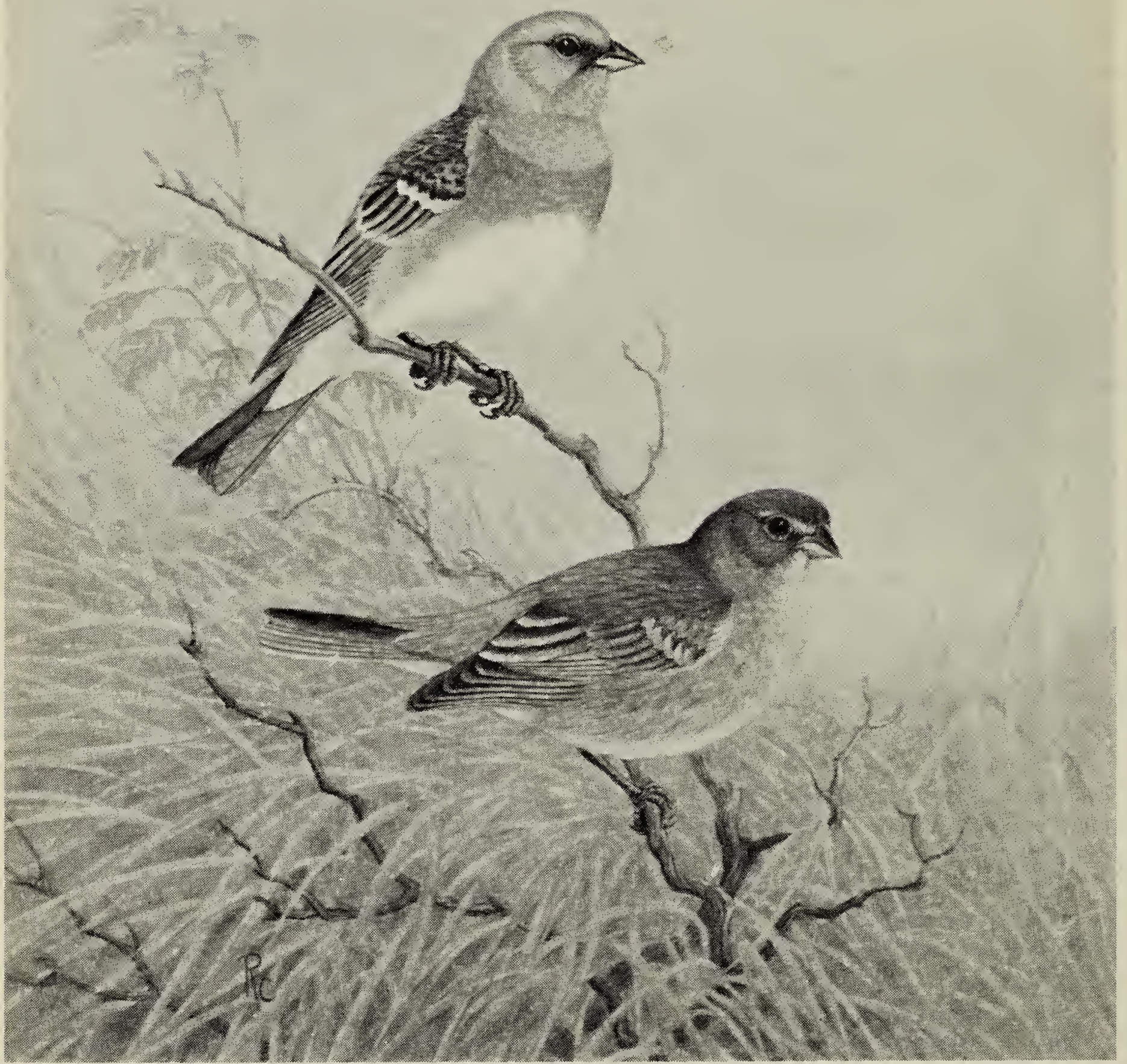

Lazuli Bunting from a Ralph D. Carson painting (Collection of six different paintings available from Provincial Museum and Archives of Alberta, Edmonton, $50 \notin$ each or 2.50 for the set of six.)

point at which the species has been seen in Manitoba, and the October 11 sighting is the latest fall one to date. The total numbers observed this fall considerably exceed the maximum of two reported in any previous year. However, we have no evidence that the species breeds this far east, and can only conclude that these were migrants several hundred miles from their usual breeding areas. Lazulis have been reported east of their range in other years (Virginia: Audubon Field-Notes, 20:409, 1966; Wisconsin: Audubon Field-Notes, 21:512, 1967) and are listed as casual visitors in western Minnesota and western Missouri (A.O.U., 1957). Godfrey's (1966) breeding distribution map summarizes the known furthermost extent of breeding, but does not indicate that the species abundance varies every year, particularly at the periphery of its range. A fluctuation in density from 


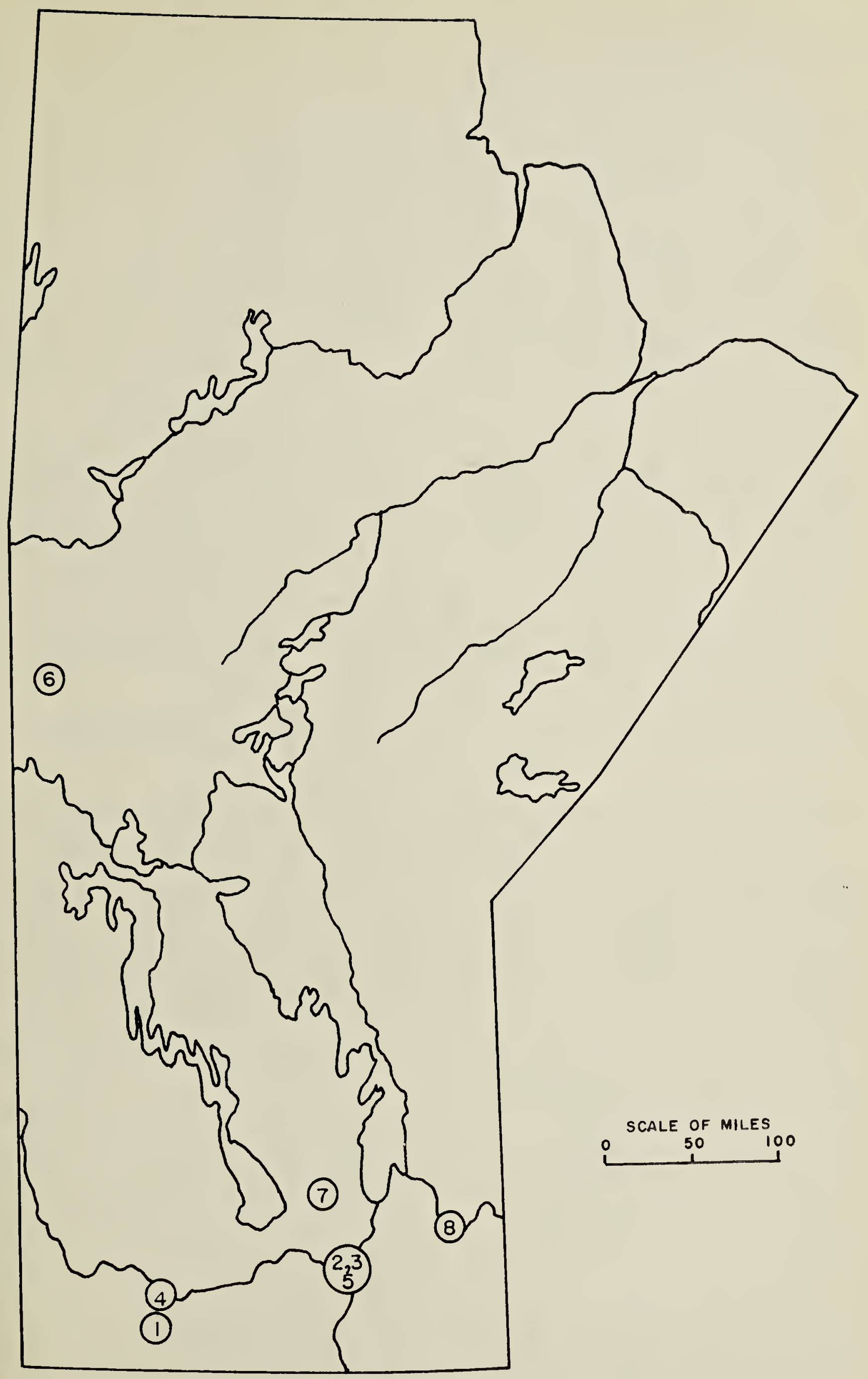

Fig. 2 Locations of Manitoba sightings of Lazuli Buntings.

The numbers refer to sightings listed in Table 1.

March, 1972 


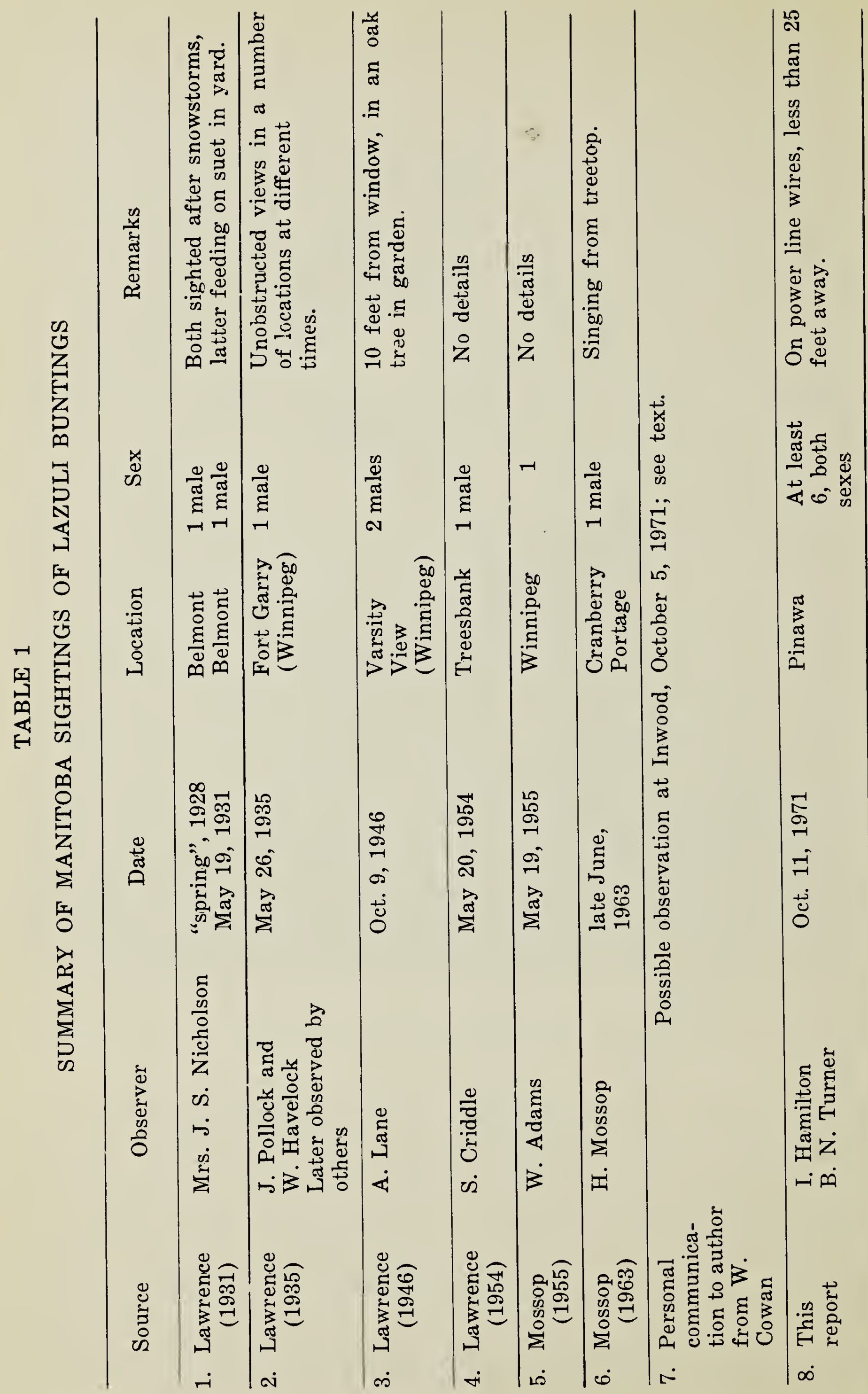


year to year is indicated by the Saskatchewan records as reported in The Blue Jay. Since 1942, a Saskatchewan sighting has been recorded in less than half the years to the present. Sightings in Manitoba would therefore be rarer, due to its position east of the breeding range, and irregular, as they have been in Saskatchewan. However, it is apparent that the species can be expected, at least in some years, to migrate through Manitoba, and a familiarity with the species characteristics would prepare the Manitoba birdwatcher to recognize this colourful species.

\section{Acknowledgments}

Herbert W. R. Copland and Robert W. Nero aided in locating previous Manitoba records of the Lazuli Bunting. Dr. Nero and my WNRE colleagues provided useful comments on the manuscript. R. E. Stewart is thanked for providing his extensive North Dakota records, and W. E. Godfrey for his Estevan record.

\section{LITERATURE CITED}

American Ornithologits' Union Check-list Commitee. 1957. Check-list of North American birds. 5 th ed. Lord Baltimore Press, Baltimore, Maryland. $691 \mathrm{pp}$.

Bent, A. C. 1968. Life histories of North American cardinals, buntings, towhees, finches, sparrows and allies. U.S. Natl. Mus. Bull. 237, part $1: 111-132$.

Godfrey, W. E. 1966. The birds of Canada. Natl. Mus. Can. Bull. 203, Queen's Printers, Ottawa, $428 \mathrm{pp}$.

Lawrence, A. G. 1931. "Chickadee Notes" No. 549. Winnipeg Free Press, Oct. 2.

Lawrence, A. G. 1935. "Chickadee Notes" No. 710. Winnipeg Free Press, May 31.

Lawrence, A. G. 1946. "Chickadee Notes" No. 1331. Winnipeg Free Press, November 22.

Lawrence, A. G. 1954. "Chickadee Notes" No. 1726. Winnipeg Free Press, June 18.

Mossop, H. 1955. "Chickadee Notes" No. 19. Winnipeg Free Press, May 27.

Mossop, H. 1963. "Chickadee Notes" No. 443. Winnipeg Free Press, July 13

Nero, R. W. and M. R. Lein. 1971. Birds of Moose Mountain, Saskatchewan. Sask. Nat. Hist. Soc., Spec. Publ. No. 7. 56 pp.

Peterson, R. T. 1961. A field guide to western birds. Houghton Mifflin, Boston. 2nd ed. 366 pp.

Sibley, C. G., and L. L. Short, Jr. 1959. Hybridization in the buntings (Passerina) of the Great Plains. Auk $75: 443-463$.

\section{WESTERN GREBE FATALLY ENTANGLED IN FISHING LINE}

by Robert W. Nero, Department of Mines, Resources and Environmental Management, Box 19, 139 Tuxedo Blvd., Winnipeg R3C OV8

Birds are affected by a host of natural and unnatural or man-made mortality factors. More than two million observations of non-hunting mortality in waterfowl, for example, were recorded in the following categories: "pollution, collisions, predation, disease, weather, and miscellaneous" (Cornwell, 1968).

Some unusual accidents have befallen Western Grebes in the Prairie Provinces: large-scale deaths due to a sudden freeze-up were noted in Alberta (Nero, 1960) ; "wetting", a break-down in the waterproofing system of plumage, and even entanglement in a rubber prophylactic ring (with probable eventual death) occurred at a sewage lagoon in Saskatchewan (Nero, 1968); and large numbers were drowned in gill-nets set for fish in Manitoba (Bartonek, 1965).
The hazard to birds of fishermen's lures and even the possibility of birds becoming entangled in fishermen's lines while the latter are fishing has been noted (Campbell, 1967). A recent observation involving a Western Grebe indicates the additional hazard of discarded lengths of fishing line.

On September 23, 1971, a dead adult Western Grebe was found floating upside down in shallow water adjacent to an earth-fill dam across a narrow inlet at the Last Mountain Lake Wildlife Area, Saskatchewan. As the photograph shows, the bird was trapped in several feet of monofilament nylon fishing line wrapped around its neck and one foot. The line was tightly drawn in two or three loops around the neck, presumably causing death by strangulation or drowning. The grebe may have become entangled in an 